J. Natn. Sci. Coun. Sri Lanka 198715 (2) : 217-226

\title{
IMMOBILIZATION OF ALPHA-AMYLASE AND GLUCOAMYLASE TO SEPHAROSE - 4B
}

\author{
V. ARASARATNAM AND K. BALASUBRAMANIAM \\ Department of Biochemistry, Faculty of Medicine, \\ University of Jaffna, Jaffna, Sri Lanka.
}

(Date of receipt : 17 January 1986)

(Date of acceptance : 20 August 1987)

\begin{abstract}
Alpha amylase was coupled to Sepharose - 4B (activated by both electrophilic and nucleophilic methods using cyanogen bromide). Cyanogen bromide concentration was found to be directly proportional to the concentration of the alpha amylase protein coupled. When $120 \mathrm{mg} \mathrm{CNBr} / \mathrm{g}$ wet gel was used for the activation by electrophilic and nucleophilic methods, the alpha amylase coupled was $70 \%$ and $19 \%$ respectively. The coupling of alpha amylase and glucoamylase to the cyanogen bromide activated gel was linear up to $10 \mathrm{~min}$ and reached a maximum by $0.5 \mathrm{~h}$. When the concentrations of alpha amylase and glucoamylase used for coupling were increased from $1-1000 \mu \mathrm{g} / \mathrm{g}$ wet gel, the percentage activity of the immobilized enzymes decreased and was inversely proportional to the log of enzyme concentration added for coupling. The total activity of these cnzymes increased with an increase in enzyme concentration.
\end{abstract}

\section{Introduction}

The water soluble enzyme proteins are immobilized to water insoluble matrices for their repeated utilization and for continuous systems. Immobilization of proteins has been carried out since the late 1960's by various methods using different water insoluble matrices. ${ }^{2,10}$

To immobilize an enzyme protein to a water insoluble matrix, the matrix should first be activated. Axen et al who were the pioneers in the activation of Sepharose $-4 \mathrm{~B}$ used cyanogen bromide ${ }^{1,9}$ as the reagent. This method of activation was carried out in an alkaline medium and the active species produced results in a negative charge hence it is called a nucleophilic method of activation.

Kohn and Wilcheck developed a method to activate the same matrix (Sepharose - 4B) at neutral $\mathrm{pH}$ with the reactive species having a positive charge. This method, which is called the electrophilic method of activation, is more effective than the nucleophilic method. ${ }^{6}$

Although general conditions for activation of matrices and coupling of proteins are known, the optimal conditions for coupling of alpha amylase and glucoamylase, (enzymes of industrial importance) are seldom published. 
Further, the electrophilic and nucleophilic methods of activation of matrices have not been compared previously. In our work we have used both the electrophilic and nucleophilic methods of activation and studied the effect of cyanogen bromide concentration on the activation of the Sepharose $-4 \mathrm{~B}$ by the two methods. In addition, the optimal conditions for the coupling of alpha amylase $(1,4-\alpha-\mathrm{D}$ glucan glucanohydrolase; EC 3.2.1.1.) and glucoamylase $(1,4-\alpha-\mathrm{D}$ glucan glucohydrolase; EC 3.2.1.3) to the cyanogen bromide activated Sepharose $-4 \mathrm{~B}$ were investigated.

\section{Experimental}

\subsection{Materials}

Alpha amylase from hog pancreas (Sigma Chemical Company, USA), glucoamylase from Aspergillus niger (CISIR, Sri Lanka) and Sepharose - 4B (Pharmacia Fine Chemicals, Sweden) were used in this study.

\subsection{Preparation of cyanogen bromide}

Cyanogen bromide was prepared according to the method described previqusly ${ }^{5}$ with minor modifications (see results and discussion).

\subsection{Electrophilic activation of Sepharose $-4 \mathrm{~B}$ by cyanogen bromide}

Sepharose - 4B (25 g wet weight) was washed thoroughly with cold distilled water followed by $250 \mathrm{ml}$ portions of $30 \%$ cold acetone and $60 \%$ cold acetone in a Buchner funnel. The washed gel was divided into 5 different, $5 \mathrm{~g}$ portions and each was suspended in $5 \mathrm{ml}$ of $60 \%$ acetone. To these $5 \mathrm{~g}$ portions of gel different amounts of cyanogen bromide in $60 \%$ acetone $(10,20,40,80 \& 120 \mathrm{mg} / \mathrm{g}$ wet gel) were added while the gel portions were stirred continually. Varying amounts of triethylamine (TEA) in $60 \%$ acetone $(16.4,32.8,65.6,131.2 \& 196.8 \mathrm{mg} / \mathrm{g}$ wet gel) were added to the gel portions dropwise for $3 \mathrm{~min}$. The $\mathrm{pH}$ of the medium was found to be neutral. The $\mathrm{CNBr}$ : TEA concentration was $1 \mathrm{M}: 1.5 \mathrm{M}$ respectively. ${ }^{6}$

\subsection{Nucleophilic activation of Sepharose - 4B by cyanogen bromide}

Varying amounts of $\mathrm{NaOH}$ in $60 \%$ acetone $(5.66,11.32,22.64,45.28$ and $67.92 \mathrm{mg} / \mathrm{g}$ wet gel) were used in place of triethylamine. The rest of the procedure was as in section 2.3. The concentration of $\mathrm{CNBr}: \mathrm{NaOH}$ added was $1 \mathrm{M}: 1.5 \mathrm{M}$. The $\mathrm{pH}$ of the medium was 12 . 


\subsection{Coupling of alpha amylase to the activated gel}

The cyanogen bromide activated Sepharose - 4B ( 5 g portions) was transferred into screw cap tubes and suspended in $5 \mathrm{ml}$ of coupling buffer $(0.1 \mathrm{M}$ bicarbonate $-0.5 \mathrm{M} \mathrm{NaCl}$ buffer $\mathrm{pH}$ 8.3). To these were added alpha amylase in solution ( $1 \mathrm{mg} / \mathrm{g}$ wet gel). The mixture was agitated for $2 \mathrm{~h}$ at room temperature in a shaker water bath. The gel portions were washed thrice with coupling buffer.

In order to block the excess activated groups on the mixture, $20 \mathrm{ml}$ - of $1 \mathrm{M}$ ethanolamine in water $(\mathrm{pH} 8.3)$ were added to the gel and the mixture agitated for $2 \mathrm{~h}$ at room temperature. The gel was washed thrice alternatively with coupling buffer and with $0.1 \mathrm{M}$ acetate $-0.5 \mathrm{M} \mathrm{NaCl}$ buffer (pH 4).

The gel was washed finally with $0.02 \mathrm{M}$ phosphate buffer $\mathrm{pH} 6.9$ (in which alpha amylase is more stable). The immobilized enzyme protein was estimated by the Kjeldahl method. ${ }^{8}$

\subsection{Effect of time on coupling of alpha amylase and glucoamylase}

The time for coupling of enzyme molecules to the activated Sepharose-4B was varied between 0 and $120 \mathrm{~min}$. The coupled alpha amylase and glucoamylase were estimated, indirectly, by measuring the activity of coupled enzymes using the dinitrosalicylic acid method. ${ }^{3,4}$. The gel coupled to glucoamylase was finally washed with $0.01 \mathrm{M}$ acetate buffer $\mathrm{pH} 4.8$ (in which the enzyme is more stable).

\subsection{Effect of concentration of alpha amylase and glucoamylase on coupling}

Varying amounts of alpha amylase and glucoamylase $(1-1000 \mu \mathrm{g} / \mathrm{g}$ wet gel $)$ were added to the activated gel for coupling. The coupled alpha amylase and glucoamylase were estimated, indirectly, by testing for their activity.

In Figure 4, the activity (\%) is the amount of immobilized alpha amylase activity/the soluble alpha amylase activity added $\times 100$; and total activity refers to the amount of activity in the immobilized alpha amylase.

\section{Result and Discussion}

\subsection{Synthesis of cyanogen bromide}

A yield of $25.45 \mathrm{~g}$ of $\mathrm{CNBr}$ was obtained from $50 \mathrm{~g}$ of bromine which was $76.83 \%$ the theoretical yield. The melting point of the product was $49^{\circ} \mathrm{C}$ (observed $48^{\circ}-50^{\circ} \mathrm{C}$ ) which showed the purity of the product. The 
following experimental details were noted: (a) A short wide air condensor was used since $\mathrm{CNBr}$ clogs the narrow long condensor at room temperature. (b) To reduce the volatility of the product the receiving flask was kept in an ice bath. Cyanogen bromide being soluble only in water at $50^{\circ} \mathrm{C}$, it is advisable to dissolve it in solvents such as acetonitrile, dimethyl sulphoxide and acetone. ${ }^{7}$

\subsection{Activation and coupling}

\subsubsection{Method of Activation}

A linear relationship between the amount of $\mathrm{CNBr}$ used and the amount of alpha amylase protein coupled to the Sepharose-4B was obtained for both the electrophilic and the nucleophilic methods (Figure 1). This showed that the degree of activation was directly proportional to the amount of $\mathrm{CNBr}$ used for activation.

When $120 \mathrm{mg} \mathrm{CNBr} / \mathrm{g}$ wet Sepharose-4B was used in the electrophilic and nucleophilic methods of activation and $1 \mathrm{mg}$ alpha amylase/g wet gel was added for coupling, the alpha amylase protein coupled was $70 \%$ and $19 \%$ respectively. From these observations it was concluded that the electrophilic method was better than the nucleophilic method and needed lesser amounts of $\mathrm{CNBr}$ for greater activation.

Kohn and Wilcheck postulated that in the nucleophilic method of activation the cyanate esters were formed and the alkaline medium hydrolysed the active cyanate esters. To compensate for this hydrolysis a high concentration of $\mathrm{CNBr}$ is essential. Hence the percentage of activation is very low even at a high $\mathrm{CNBr}$ concentration. In the electrophilic method of activation, triethylamine reacts with $\mathrm{CNBr}$ to form a highly reactive triethylammonium nitrile complex (Figure 2) and this complex has a higher electrophilicity than CNBr. The complex reacts with the hydroxyl group of the gel and leads to a higher degree of activation. Since the $\mathrm{pH}$ of the medium is 7 there is little or no hydrolysis of the cyanate esters.

\subsubsection{Coupling}

The buffer used for coupling had a high salt concentration $(0.5 \mathrm{M} \mathrm{NaCl})$ to minimise the protein - protein adsorption caused by the polyelectrolyte nature of the protein and to reduce the mutual repulsion between the enzyme and the support where the proteins are negatively charged at higher $\mathrm{pH}$ values ( $\mathrm{pH} 8.3)$.

The adsorbed enzymes present in the immobilized enzyme preparations were removed by cyclic washings using high and low $\mathrm{pH}$ buffer 


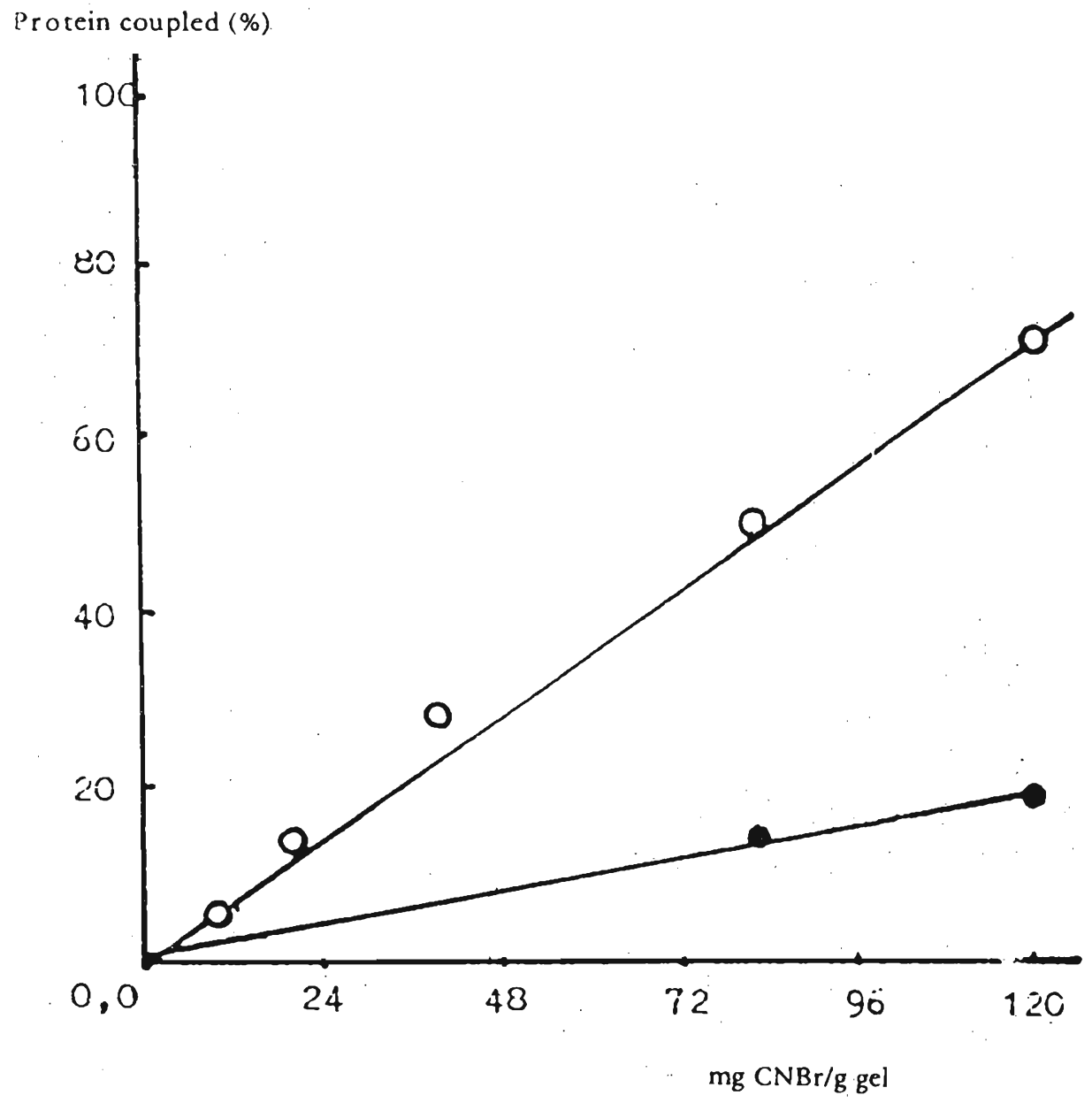

Figure 1. Effect of cyanogen bromide concentration on activation of Sepharose - 4B when $\mathrm{NaOH}$ and TEA $\rightarrow \longrightarrow$ were used. 


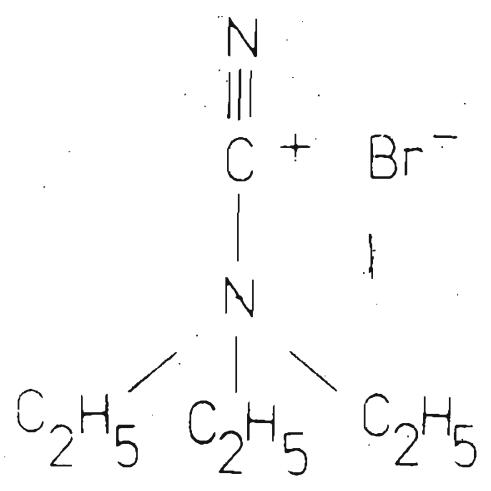

Figure 2. Triethylammonium nitrile complex.

solutions of high ionic strengths. The washings were carried out within the least possible time as the extreme $\mathrm{pH}$ values could affect the stability of immobilized enzymes.

Sepharose was selected because its high porosity allows the penetration of large macromolecules. Adsorption is an insignificant problem with Sepharose.

The coupling of alpha amylase and glucoamylase to $\mathrm{CNBr}$ activated Sepharose-4B was found to be linear for $10 \mathrm{~min}$ and reached its maximum by $0.5 \mathrm{~h}$. After $0.5 \mathrm{~h}$ there was no significant increase in coupling (Figure 3 ).

\subsection{Activity of enzymes}

When the amount of enzymes added for coupling was increased from $1-1000 \mu \mathrm{g} / \mathrm{g}$ wet gel, the percentage activity of the immobilized enzymes decreased and the total activity of enzyme coupled increased (Figures 4 and 5). The decrease in percentage activity may be due to the steric effect of the enzyme molecules coupled to the solid support. ${ }^{7}$. 


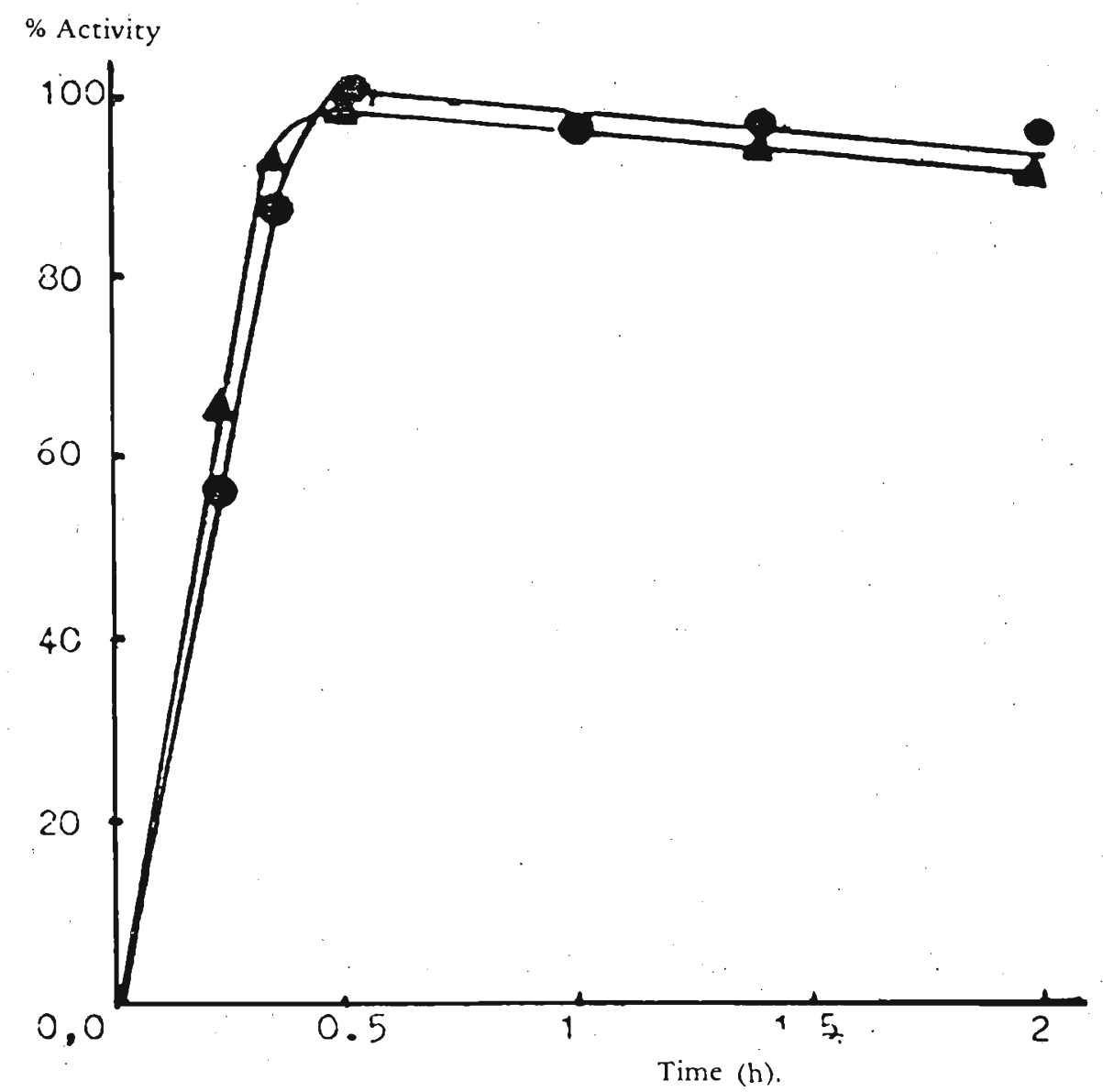

Figure 3. Effect of time on coupling of ligands to cyanogen bromide activated Sepharose-4B

$\longrightarrow \alpha$-amylase ; $\longrightarrow$ glucoamylase

(Each point is the average of duplicate determinations). 


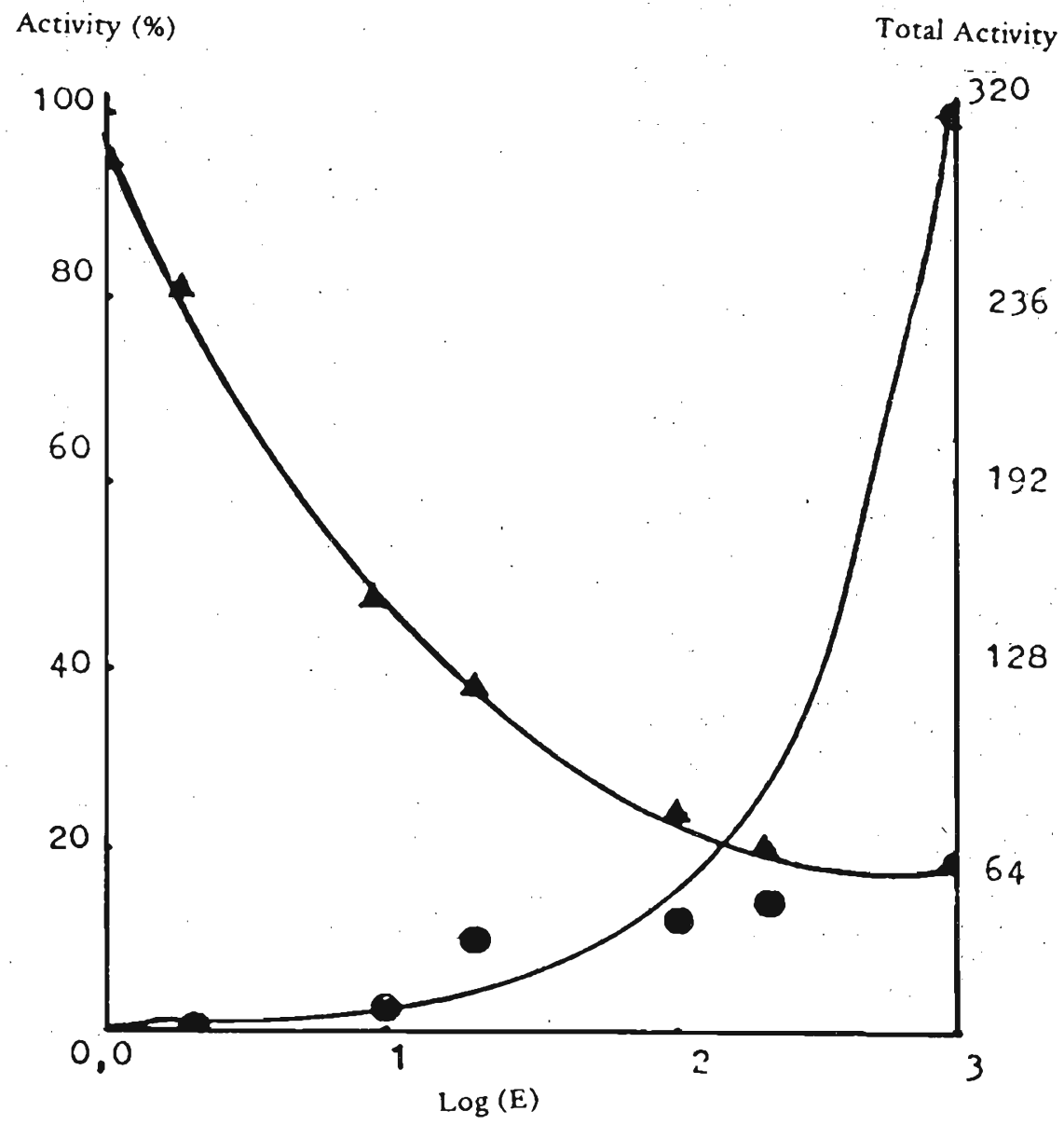

Figure 4. Effect of $\alpha$-amylase concentration ( $\mu \mathrm{g} / \mathrm{g}$ wet gel) added on the degree of immobilization. $\sim$ Activity ;

$\longrightarrow$ Total activity. (Each point is the average of duplicate determination.). 


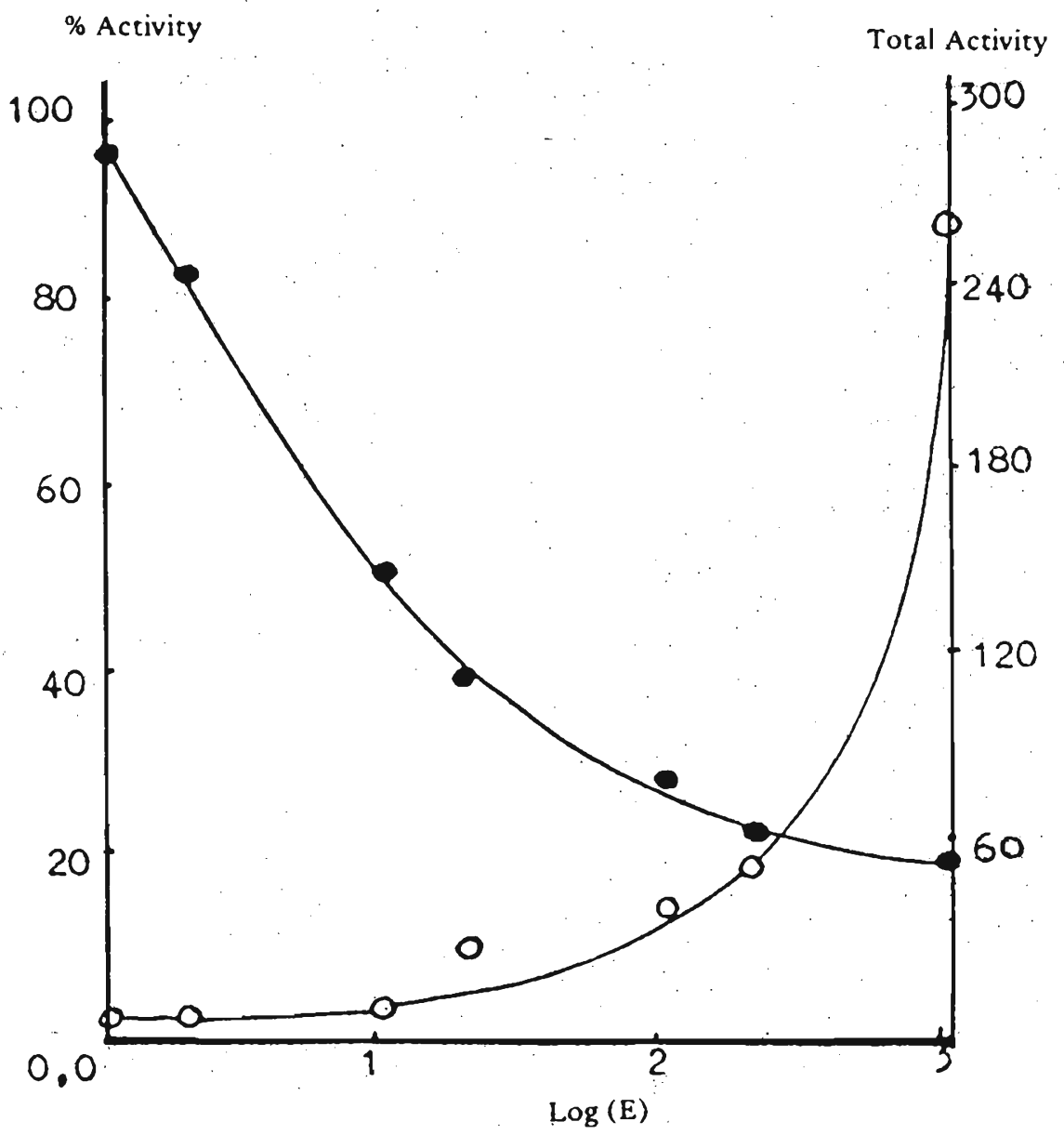

Figure 5. Effect of glucoamylase concentration ( $\mu \mathrm{g} / \mathrm{g}$ wet gel) added on the degree of immobilization. (Each point is the average of duplicate determinations). $\longrightarrow \%$ Activity ; $\longrightarrow$ Total activity 


\section{References}

1. AXEN, R., PORATH, J. \& ERNBACK, S. (1967) Nature, 214: 1302.

2. BARKER, S.A., SOMERS, P.J. \& EPTON, R. (1970) Carbobyd. Res. 14: 323.

3. BERGMEYER, H. U. (1974) Methods of enzymatic analysis II. pp. 885-890. Academic Press Inc., New York and London.

4. JANSZ, E.R., PIERIS, N., JEYARAJ, E.E. \& DE SILVA, N. (1977) J. Natn. Sci. Coun. Sri Lanka 5: 59.

5. HARTMANN, W.W. \& DREGER, E.E. (1943) Organic synthesis collective 2: 150. Ed. All Blatt, John Wiley and Sons, New York.

.6. KOHN, J. \& WILCHECK, M. (1982) Biochem. Biopbys. Res. Communic. 107(3): 878.

7. LOWE, C.R. (1982) An introduction to affinity chromatography. pp. 293-341. Elsevier Biomedical Press., Amsterdam, New York. Oxford.

8. PERSON, D. (1976) The Chemical Analysis of Food pp. 9-12. Churchill Living Stone, Edinburgh, London and New York.

9. PORATH, J., ASBERG, K., DREVIN, H. \& AXEN, R. (1973) J. Chromatography 86: 53 .

10. ZABORSKY, O.R. (1974) Immobilized Enzymes, Chemical Rubber Co., Cleveland, Ohio. 